CASE REPORT

\title{
Neonatal presentation of familial glucocorticoid deficiency resulting from a novel splice mutation in the melanocortin 2 receptor accessory protein
}

\author{
V Jain, L A Metherell ${ }^{1}$, A David ${ }^{1}$, R Sharma, P K Sharma ${ }^{2}$, A J L Clark ${ }^{1}$ and L F Chan ${ }^{1}$ \\ Division of Paediatric Endocrinology, Department of Paediatrics, All India Institute of Medical Sciences, New Delhi 110 029, India, ${ }^{1}$ Barts and The London \\ School of Medicine and Dentistry, William Harvey Research Institute, Centre for Endocrinology, Queen Mary University of London, Charterhouse Square, \\ London EC1M 6BQ, UK and ${ }^{2}$ Division of Neonatology, Department of Paediatrics, All India Institute of Medical Sciences, New Delhi 110 029, India \\ (Correspondence should be addressed to LF Chan; Email: l.chan@qmul.ac.uk)
}

\begin{abstract}
Background: Familial glucocorticoid deficiency (FGD) is a rare autosomal recessive disorder characterised by isolated glucocorticoid deficiency. Mutations in the ACTH receptor/melanocortin 2 receptor $(M C 2 R)$, the MC2R accessory protein $(M R A P)$ or the STAR protein (STAR) cause FGD types 1, 2 and 3, respectively, accounting for $\sim 50 \%$ of all cases.

Patient and methods: We report a neonate of Indian origin, who was diagnosed with FGD in the first few days of life. He presented with hypoglycaemic seizures and was noted to have generalised intense hyperpigmentation and normal male genitalia. Biochemical investigations revealed hypocortisolaemia (cortisol $0.223 \mu \mathrm{g} / \mathrm{dl}$; NR 1-23 $\mu \mathrm{g} / \mathrm{dl}$ ) and elevated plasma ACTH (170 pg/ml). Serum electrolytes, aldosterone and plasma renin activity were normal. Peak cortisol following a standard synacthen test was $0.018 \mu \mathrm{g} / \mathrm{dl}$. He responded to hydrocortisone treatment and continues on replacement. Patient DNA was analysed by direct sequencing. The effect of the novel mutation was assessed by an in vitro splicing assay using wild type and mutant heterologous minigenes.

Results: A novel homozygous mutation c.106+2_3dupTA was found in the MRAP gene. Both parents were heterozygous for the mutation. In an in vitro splicing assay, the mutation resulted in the skipping of exon 3. Conclusion: We have identified a novel MRAP mutation where disruption of the intron 3 splice-site results in a prematurely terminated translation product. This protein (if produced) would lack the transmembrane domain that is essential for MC2R interaction. We predict that this would cause complete lack of ACTH response thus explaining the early presentation in this case.
\end{abstract}

European Journal of Endocrinology 165 987-991

\section{Introduction}

Familial glucocorticoid deficiency (FGD) is a rare autosomal recessive disorder which manifests as isolated glucocorticoid deficiency with normal mineralocorticoid function (1). This potentially lethal condition is caused by adrenal resistance to ACTH and is clinically characterised by low serum cortisol concentrations in the presence of markedly elevated plasma ACTH levels. FGD patients typically present with hyperpigmentation, hypoglycaemic seizures and failure to thrive in the neonatal period or late childhood $(1,2)$. However, some milder genotypes have been presented in later years $(3,4)$.

FGD is a genetically heterogeneous entity. Inactivating mutations in the ACTH receptor also known as the melanocortin 2 receptor (MC2R) were first identified as the cause of FGD in $1993(5,6)$. This is now termed FGD type 1 (OMIM\#202200) and accounts for up to $25 \%$ of cases. In 2005, Metherell et al. (7) showed that mutations in the MC2R accessory protein (MRAP), which is essential for trafficking of MC2R from the endoplasmic reticulum (ER) to the cell surface and subsequent signalling in response to ACTH, are responsible for a further $\sim 20 \%$ of FGD cases, now named FGD type 2 (OMIM \#607398). To date, over 25 loss-of-function mutations in MC2R and 11 in MRAP have been reported $(1,4,8)$. These MRAP mutations are summarised in Table 1. Recently, certain 'less severe' mutations in STAR protein (STAR) (R192C and R188C) have been reported to be responsible for a phenotype identical to FGD types 1 and 2 and classified as FGD type 3 (3). Over the last few years we have identified cases of FGD that vary from the classical phenotype. These include cases of late onset FGD $(3,4)$, cases describing mild disturbances in angiotensin-renin-aldosterone axis in severe FGD $(9,10)$ and genetic overlap with conditions associated with mineralocorticoid insufficiency (3). This adds to the complexity of making a diagnosis and highlights the importance of genetic testing. commercial use, distribution, and reproduction in any medium, provided the original work is properly cited. 
Table 1 Summary of published and unpublished MRAP mutations. The majority of mutations are predicted to result in absent or significantly truncated protein forms and hence complete loss of ACTH response. In comparison, c.76T $>C$ (p.V26A) and c.175T $>$ G (p.Y59D) have been shown to have impaired but not absent function. p.0? represents the recommended annotation when the effect on the protein is unknown as in the case of c.3G >A that affect the initiation site and the splice mutations the lead to skipping of exon 3.

\begin{tabular}{|c|c|c|c|c|}
\hline Mutation $^{\mathrm{a}}$ & $\begin{array}{l}\text { Mutation } \\
\text { type }\end{array}$ & Functional effect & Clinical presentation & References \\
\hline c. $3 G>A(p .0 ?$ or p.M1?) & MS & Unknown (? no protein produced) & Classical early onset & $(2,7,25,26)$ \\
\hline $\begin{array}{l}\text { c.17-23delACGCCTC } \\
\text { (p.N6MfsX24) }\end{array}$ & NS & Shortened protein if translated & Classical early onset & (8) \\
\hline c. $33 \mathrm{C}>\mathrm{A}(\mathrm{p} . \mathrm{Y} 11 \mathrm{X})$ & NS & Shortened protein if translated & Classical early onset & (1) \\
\hline c.76T $>C(p . V 26 A)$ & MS & $\begin{array}{l}\text { Full-length protein with amino acid } \\
\text { change - impaired cAMP generation }\end{array}$ & Late presentation & (4) \\
\hline c. $106+1 G>T(p .0 ?)$ & SS & $\begin{array}{l}\text { Skipping of exon } 3 \text { (no protein or lack } \\
\text { transmembrane domain) }\end{array}$ & Classical early onset & $(2,7)$ \\
\hline c. $106+1 \mathrm{G}>\mathrm{A}(\mathrm{p} .0 ?)$ & SS & $\begin{array}{l}\text { Skipping of exon } 3 \text { (no protein or lack } \\
\text { transmembrane domain) }\end{array}$ & Classical early onset & $(2,7)$ \\
\hline c. $106+1 G>C(p .0 ?)$ & SS & $\begin{array}{l}\text { Skipping of exon } 3 \text { (no protein or lack } \\
\text { transmembrane domain) }\end{array}$ & Classical early onset & $(2,7)$ \\
\hline c. $106+1$ delG (p.0?) & SS & $\begin{array}{l}\text { Skipping of exon } 3 \text { (no protein or lack } \\
\text { transmembrane domain) }\end{array}$ & Classical early onset & $(2,7,27)$ \\
\hline c. $106+2$ ins T (p.0?) & SS & $\begin{array}{l}\text { Skipping of exon } 3 \text { (no protein or lack } \\
\text { transmembrane domain) }\end{array}$ & Classical early onset & $(2,7)$ \\
\hline c.106+2_3dupTA (p.0?)* & SS & $\begin{array}{l}\text { Skipping of exon } 3 \text { (no protein or lack } \\
\text { transmembrane domain) }\end{array}$ & Classical early onset & This study \\
\hline c.128delG (p.V44X) & NS & Shortened protein if translated & Classical early onset & $(7,16)$ \\
\hline c. $175 T>G$ (p.Y59D) & MS & $\begin{array}{l}\text { Full-length protein with amino acid } \\
\text { change - impaired cAMP generation }\end{array}$ & Late presentation & (4) \\
\hline
\end{tabular}

MS, missense mutation; NS, nonsense mutation; SS, splice-site mutation; c., coding DNA; p., protein.

a Mutations described according to recommended nomenclature (11). Novel mutation indicated by *.

We report an Indian child with severe generalised hyperpigmentation at birth who presented with recurrent hypoglycaemic seizures from $36 \mathrm{~h}$ of life due to a novel homozygous splice mutation (c.106+2_3dupTA) in MRAP. Using an in vitro splicing assay, we demonstrate that the mutation leads to disrupted mRNA splicing and exon 3 skipping.

\section{Case history}

The index case presented at birth with intense generalised hyperpigmentation (Fig. 1A). The male infant was born at term, birth weight $2.8 \mathrm{~kg}$ to nonconsanguineous Indian parents with a fair complexion. He had normal male genitalia. There was a family history of three previous miscarriages for which no cause was identified. At $36 \mathrm{~h}$ of life, he developed high fever, lethargy and poor feeding. He was hypoglycaemic with blood glucose of $20 \mathrm{mg} / \mathrm{dl}$. Treatment with i.v. glucose was initiated but despite this he suffered four further episodes of hypoglycaemia, twice accompanied by seizures. Serum electrolytes were normal. Endocrine investigations revealed low serum cortisol $0.22 \mu \mathrm{g} / \mathrm{dl}$ (NR 1.7-14) with a flat response post administration of a standard synacthen test $0.018 \mu \mathrm{g} / \mathrm{dl}$. Normal plasma renin activity of $5.72 \mathrm{ng} / \mathrm{ml}$ per h (NR 2.0-35.0) and plasma aldosterone of $97.9 \mathrm{ng} / \mathrm{l}$ (NR supine 10-160) confirmed the diagnosis of isolated cortisol deficiency in this case. 17-OHP levels were normal $(2 \mathrm{ng} / \mathrm{ml})$ and did not rise after a standard synacthen test $(1.5 \mathrm{ng} / \mathrm{ml})$.
Plasma ACTH was measured after 3 days of hydrocortisone therapy and was $170 \mathrm{pg} / \mathrm{ml}$ (NR 10-50). The adrenal glands were not visualised on abdominal ultrasound or computed tomography of the abdomen but seen on magnetic resonance imaging and reported as bilaterally small, highlighting the difficulty of adrenal imaging in young children.

Whilst on an initial oral replacement hydrocortisone dose of $20 \mathrm{mg} / \mathrm{m}^{2}$ per day, his skin significantly lightened. Over the next 3 years he had four further episodes of hypoglycaemic seizures precipitated by viral illness. Plasma ACTH at the age of 14 months was $>2000 \mathrm{pg} / \mathrm{ml}$, related to poor treatment compliance. This improved and his dose of hydrocortisone was reduced to $15 \mathrm{mg} / \mathrm{m}^{2}$ per day. Subsequent ACTH concentrations at the age of 2 and 3.5 years were 5.7 and $25.2 \mathrm{pg} / \mathrm{ml}$ respectively.

Despite abnormal neurological tests during the neonatal period, with extinguished response on visual evoked responses and a flat curve on brainstem evoked response to audiometry, he achieved all milestones at an appropriate age with normal hearing and vision at 3.5 years of age. Aged 3.5 years his height was $87 \mathrm{~cm}$ ( -3.5 SDS) and weight $12.5 \mathrm{~kg}$ ( -2 SDS). However, the height velocity over the past year is greater than -1 SDS and the short stature may be a reflection of the short mid-parental height of $160 \mathrm{~cm}(-2.5 \mathrm{SDS})$.

In view of the diagnosis of isolated glucocorticoid insufficiency, blood was obtained from the infant and both parents and molecular genetic analysis was performed. 


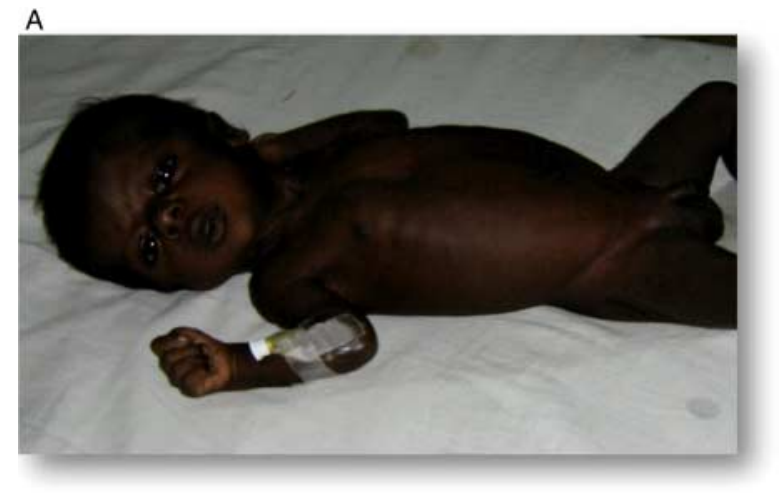

B

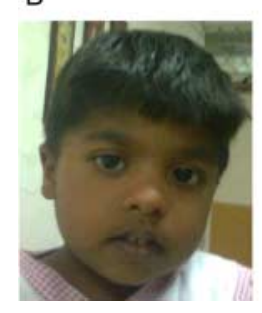

Figure $1(A)$ Intense generalised hyperpigmentation of index case at presentation in the neonatal period. (B) Current image of index case (consent obtained). Full colour version of this figure available via http://dx.doi.org/10.1530/EJE-11-0581.

\section{Materials and methods}

\section{Sequencing}

Genomic DNA was extracted from blood leucocytes. Informed patient consent was obtained. PCR and sequencing of the coding exons of $M C 2 R$ and $M R A P$ was performed using patient or parental genomic DNA. Primers were designed to intronic sequences (sequences available on request). PCR products were sequenced in both directions using ABI Prism Big Dye Sequencing kit on an ABI 377 automated DNA sequencer (Applied Biosystems). The mutation was described according to recommended nomenclature (11).

\section{In vitro splicing assay}

To demonstrate that this mutation affected mRNA splicing, MRAP exon 3 and its wild type (MRAP wt) or mutated (MRAP $\mathrm{mt}$ ) flanking intronic sequences were introduced into a well-characterised splicing reporter derived from the adenovirus major late (AdML-Par) first and second leader exons. In vitro splicing experiments were performed as described previously (12).

\section{Results}

$M C 2 R$ was found to be normal on sequencing. A novel homozygous two base pair duplication mutation at the splice junction of exon 3/intron 3 (c.106+2_3dupTA) was detected in MRAP in the affected child (Fig. 2A). Both parents were heterozygous for this mutation.

In silico, c. $106+2$ _3dupTA mutation is predicted to disrupt splicing. An in vitro splicing assay showed that after $1 \mathrm{~h}$ incubation under splicing condition, the wildtype minigene produced a band corresponding to the three exons (L1-MRAP_exon3-L2) joined together. This was confirmed by direct sequencing. The c.106 +2 3dupTA mutation in the mutant minigene caused the skipping of MRAP exon 3 and resulted in a band of 186 nucleotides corresponding to exons L1 and L2 spliced together (Fig. 2B). This was confirmed by DNA sequencing. The resulting MRAP transcript would have a foreshortened open reading frame that encodes a prematurely terminated translation product. This protein (if produced) would lack the transmembrane domain that is essential for MC2R interaction.

\section{Discussion}

We report a case of FGD presenting at birth due to a novel homozygous splice-site mutation of MRAP. In vitro splicing assay demonstrated that this mutation would cause skipping of exon 3 leading to a protein (if produced) lacking the transmembrane MC2R interacting domain.

The very early presentation of FGD and severe phenotype in our case is in keeping with the pathophysiology previously seen with MRAP splicesite and nonsense mutations $(1,2,8)$. MRAP is a small single-pass transmembrane domain protein, which is essential for the processing of the MC2R and its trafficking from the ER to the cell surface. Mapping of the domains important for action has been undertaken by two groups $(13,14)$. The transmembrane domain of MRAP encoded by exon 3 is responsible for MC2R interaction, whilst the tyrosine rich region in the $\mathrm{N}$-terminus is important for MC2R trafficking; and the C-terminus regulates MC2R cell surface expression (14). In the absence of MRAP, MC2R is retained within the ER and fails to reach the cell surface $(7,15)$.

The majority of MRAP mutations reported to date are splice-site or nonsense mutations which if translated are predicted to produce proteins lacking the transmembrane domain, leading to a complete loss of receptor function and a severe phenotype $(1,7,8$, 16). Such patients present with symptoms and signs of hypocortisolaemia very early on in life at a median age of 0.08 years (range: at birth to 1.6 years) (2). Recently, two homozygous missense mutations in MRAP have also been reported that are associated with a milder and variable phenotype (4). In contrast to the early presentation seen with MRAP splice-site/nonsense mutations, the index cases with missense mutations c. $175 \mathrm{~T}>\mathrm{G}$ (p.Y59D) and c.76T $>$ C (p.V26A) presented at the age of 4 and 18 years respectively. Importantly, the 18-year-old index patient presented with non-specific 
A

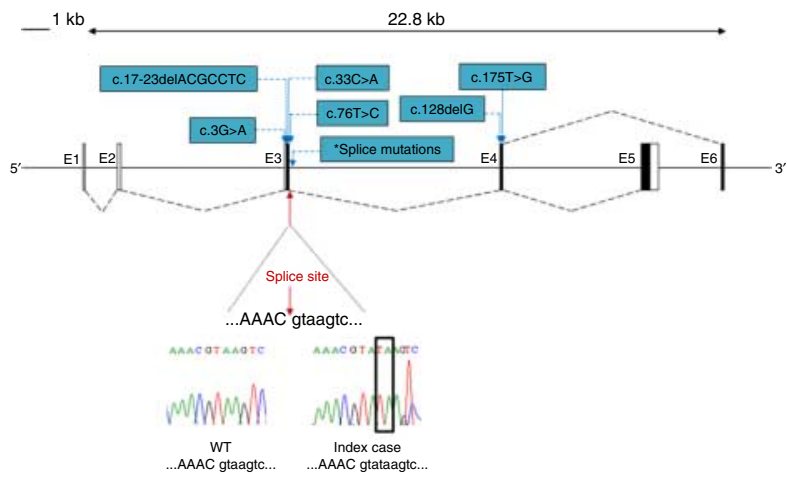

B

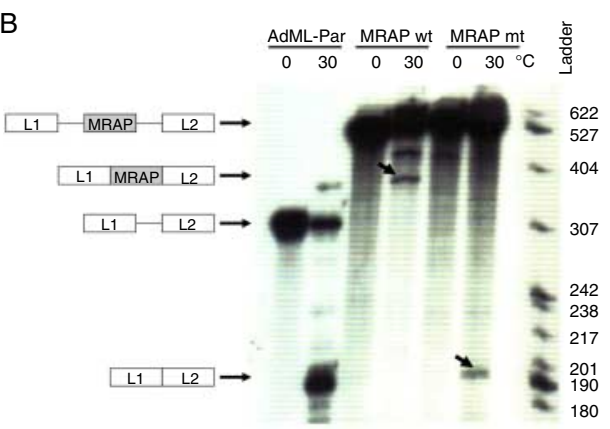

Figure 2 (A) Schematic diagram representing alternative splicing of MRAP exons 5 and 6 . Black boxes represent coding regions and black dashed lines indicate splicing. Chromatogram showing the splice mutation (red arrow). Other known MRAP mutations are shown in blue. *Indicates position of splice-site mutations (c.106+ $1 \mathrm{G}>\mathrm{T}, \mathrm{c} .106+1 \mathrm{G}>\mathrm{A}, \mathrm{c} .106+1 \mathrm{G}>\mathrm{C}, \mathrm{c} .106+1 \mathrm{del} \mathrm{G}$ and c.106+ 2insT). (B) In vitro splicing assay demonstrates that MRAP mutation C.106+2_3dupTA leads to impaired splicing and skipping of exon 3 . In this assay, MRAP exon 3 flanked by either wild type (wt) or mutated (mt; c.106+2_3dupTA) MRAP intronic sequences were introduced into a splicing reporter (AdML-Par) between the first and the second leader exons, L1 and $L 2$. The resulting minigenes, MRAP wt (L1-MRAP wt_exon3-L2), MRAP mt (L1-MRAP mt_exon3-L2) or AdML-Par (splicing reporter alone, L1-L2), were incubated in HeLa nuclear extracts for 60 min under splicing conditions at $30^{\circ} \mathrm{C}$ or pre-splicing control conditions at $0{ }^{\circ} \mathrm{C}$. Incubation temperatures, 0 or $30^{\circ} \mathrm{C}$, are indicated above each lane. The identity of the pre-mRNA and of the mRNA spliced products is schematically drawn next to the autoradiogram. The nucleotide ladder is shown on the right. Retention of MRAP exon 3 (L1-MRAPL2) is seen with MRAP wt whilst aberrant splicing resulting in skipping of MRAP exon 3 (L1-L2) is detected in MRAP mt. Bands corresponding to correct and aberrant mRNA splice products are indicated by the arrows. Full colour version of this figure available via http://dx.doi.org/10.1530/EJE-11-0581.

symptoms of fatigue, weight loss and depression. The description of these patients not only extends the phenotype of FGD but also informs us of the importance of considering this diagnosis in adults with late presentation isolated glucocorticoid deficiency.

On the other hand, more than 25 mutations reported so far in MC2R gene are missense mutations. The majority of these mutations have been shown in vitro to impair the trafficking of MC2R from ER to the cell surface and lead to a variable reduction in the receptor expression, which is $20-100 \%$ of the wild type $(2,4$, 17). As highlighted by Chung et al. (2), nonsense or frameshift mutations are associated with a severe phenotype of FGD (more common with MRAP mutations) whereas missense mutations give rise to a milder phenotype (more common with MC2R mutations).

Owing to the observation that ACTH and $\alpha$-MSH are equipotent on human melanocortin 1 receptor (MC1R) (18), hyperpigmentation observed in FGD has generally been thought to be due to high ACTH acting on the MC1R in melanocytes $(19,20)$. Indeed other conditions that result in ACTH excess, such as Cushing's disease and ectopic ACTH Cushing's syndrome can present with hyperpigmentation although this is often less intense, reflecting the lower plasma concentrations of ACTH measured in these disorders (21).

It is interesting that our patient was deeply hyperpigmented at birth. This is a feature that has been described in other case reports and would suggest that the foetal corticotrophs can produce excessive plasma ACTH in response to low foetal cortisol which in turn acts on melanocytes to promote eumelanin synthesis before birth $(22,23)$. In some FGD patients the plasma ACTH levels are difficult to normalise despite large doses of hydrocortisone and they remain pigmented. In our patient normalisation of ACTH was achievable using a dose of $15 \mathrm{mg} / \mathrm{m}^{2}$ per day.

Weight and height differences have also been described. Some patients with $M C 2 R$ mutations (FGD type 1) have been described as having tall stature $(2,24)$ although the molecular mechanism for this is uncertain. Our patient has short stature at the age of 3.5 years. This is probably consistent with the short stature of his parents. Early onset obesity has also been reported in one family with MRAP mutation (16), this is not a feature noted in our patient.

In conclusion, we have presented a newborn with FGD type 2, presenting with intense hyperpigmentation and hypoglycaemic seizures. He was found to have a novel splice-site mutation in the MRAP gene that would cause complete loss of ACTH response, hence explaining the early presentation seen in the case. Early diagnosis and appropriate therapy enabled him to achieve normal developmental milestones despite initial abnormal tests.

\section{Declaration of interest}

The authors declare that there is no conflict of interest that could be perceived as prejudicing the impartiality of the research reported.

\section{Funding}

This work was supported by a Medical Research Council/Academy of Medical Sciences Clinician Scientist Fellowship to L F Chan (grant number G0802796). L A Metherell is supported by a Medical Research Council New Investigator Research Grant (grant number G0801265). 


\section{References}

1 Chan LF, Clark AJ \& Metherell LA. Familial glucocorticoid deficiency: advances in the molecular understanding of ACTH action. Hormone Research 200869 75-82. (doi:10.1159/ 000111810)

2 Chung TT, Chan LF, Metherell LA \& Clark AJ. Phenotypic characteristics of familial glucocorticoid deficiency (FGD) type 1 and 2. Clinical Endocrinology 201072 589-594. (doi:10.1111/j. 1365-2265.2009.03663.x)

3 Metherell LA, Naville D, Halaby G, Begeot M, Huebner A, Nurnberg G, Nurnberg P, Green J, Tomlinson JW, Krone NP, Lin L, Racine M, Berney DM, Achermann JC, Arlt W \& Clark AJ. Nonclassic lipoid congenital adrenal hyperplasia masquerading as familial glucocorticoid deficiency. Journal of Clinical Endocrinology and Metabolism 200994 3865-3871. (doi:10.1210/jc.20090467)

4 Hughes CR, Chung TT, Habeb AM, Kelestimur F, Clark AJL \& Metherell LA. Missense mutations in the melanocortin 2 receptor accessory protein that lead to late onset familial glucocorticoid deficiency type 2. Journal of Clinical Endocrinology and Metabolism 201095 3497-3501. (doi:10.1210/jc.2009-2731)

5 Tsigos C, Arai K, Hung W \& Chrousos GP. Hereditary isolated glucocorticoid deficiency is associated with abnormalities of the adrenocorticotropin receptor gene. Journal of Clinical Investigation 199392 2458-2461. (doi:10.1172/JCI116853)

6 Clark AJ, McLoughlin L \& Grossman A. Familial glucocorticoid deficiency associated with point mutation in the adrenocorticotropin receptor. Lancet 1993341 461-462. (doi:10.1016/01406736(93)90208-X)

7 Metherell LA, Chapple JP, Cooray S, David A, Becker C, Ruschendorf F, Naville D, Begeot M, Khoo B, Nurnberg P, Huebner A, Cheetham ME \& Clark AJ. Mutations in MRAP, encoding a new interacting partner of the ACTH receptor, cause familial glucocorticoid deficiency type 2. Nature Genetics 200537 166-170. (doi:10.1038/ng1501)

8 Modan-Moses D, Ben-Zeev B, Hoffmann C, Falik-Zaccai TC, Bental YA, Pinhas-Hamiel O \& Anikster Y. Unusual presentation of familial glucocorticoid deficiency with a novel MRAP mutation. Journal of Clinical Endocrinology and Metabolism 200691 37133717. (doi:10.1210/jc.2006-0687)

9 Lin L, Hindmarsh PC, Metherell LA, Alzyoud M, Al Ali M, Brain CE, Clark AJ, Dattani MT \& Achermann JC. Severe loss-of-function mutations in the adrenocorticotropin receptor (ACTHR, MC2R) can be found in patients diagnosed with salt-losing adrenal hypoplasia. Clinical Endocrinology 200766 205-210. (doi:10. $1111 / \mathrm{j} .1365-2265.2006 .02709 . \mathrm{x})$

10 Chan LF, Metherell LA, Krude H, Ball C, O'Riordan SM, Costigan C, Lynch SA, Savage MO, Cavarzere P \& Clark AJ. Homozygous nonsense and frameshift mutations of the ACTH receptor in children with familial glucocorticoid deficiency (FGD) are not associated with long-term mineralocorticoid deficiency. Clinical Endocrinology 200971 171-175. (doi:10.1111/j.1365-2265. 2008.03511.x

11 den Dunnen JT \& Antonarakis SE. Mutation nomenclature extensions and suggestions to describe complex mutations: a discussion. Human Mutation 200015 7-12. (doi:10.1002/ (SICI)1098-1004(200001)15:1 < 7::AID-HUMU4 > 3.0.CO;2-N)

12 Metherell LA, Akker SA, Munroe PB, Rose SJ, Caulfield M, Savage MO, Chew SL \& Clark AJ. Pseudoexon activation as a novel mechanism for disease resulting in atypical growth-hormone insensitivity. American Journal of Human Genetics $200169641-$ 646. (doi:10.1086/323266)

13 Sebag JA \& Hinkle PM. Regions of melanocortin 2 (MC2) receptor accessory protein necessary for dual topology and MC2 receptor trafficking and signaling. Journal of Biological Chemistry $2009 \mathbf{2 8 4}$ 610-618. (doi:10.1074/jbc.M804413200)

14 Webb TR, Chan L, Cooray SN, Cheetham ME, Chapple JP \& Clark AJ. Distinct melanocortin 2 receptor accessory protein domains are required for melanocortin 2 receptor interaction and promotion of receptor trafficking. Endocrinology $2009 \mathbf{1 5 0}$ 720-726. (doi:10.1210/en.2008-0941)

15 Noon LA, Franklin JM, King PJ, Goulding NJ, Hunyady L \& Clark AJ. Failed export of the adrenocorticotrophin receptor from the endoplasmic reticulum in non-adrenal cells: evidence in support of a requirement for a specific adrenal accessory factor. Journal of Endocrinology 2002174 17-25. (doi:10.1677/joe.0. 1740017)

16 Rumie H, Metherell LA, Clark AJ, Beauloye V \& Maes M. Clinical and biological phenotype of a patient with familial glucocorticoid deficiency type 2 caused by a mutation of melanocortin 2 receptor accessory protein. European Journal of Endocrinology 2007157 539-542. (doi:10.1530/EJE-07-0242)

17 Chung TT, Webb TR, Chan LF, Cooray SN, Metherell LA, King PJ, Chapple JP \& Clark AJ. The majority of adrenocorticotropin receptor (melanocortin 2 receptor) mutations found in familial glucocorticoid deficiency type 1 lead to defective trafficking of the receptor to the cell surface. Journal of Clinical Endocrinology and Metabolism 200893 4948-4954. (doi:10.1210/jc.2008-1744)

$18 \mathrm{Lu} \mathrm{D}$, Haskell-Leuvano C, Inge Vage D \& Cone RD. The melanocortin-1-receptor. In The Melanocortin Receptors, pp 309-339. Ed. RD Cone. New Jersey: Humana Press, 2000.

19 Hunt G, Donatien PD, Lunec J. Todd C, Kyne S \& Thody AJ. Cultured human melanocytes respond to MSH peptides and ACTH. Pigment Cell Research 19947 217-221. (doi:10.1111/j. 1600-0749.1994.tb00052.x)

20 Clark AJ \& Weber A. Adrenocorticotropin insensitivity syndromes. Endocrine Reviews 199819 828-843. (doi:10.1210/er.19.6.828)

21 Biller BMK, Grossman AB, Stewart PM, Melmed S, Bertagna X, Bertherat J, Buchfelder M, Colao A, Hermus AR, Hofland LJ, Klibanski A, Lacroix A, Lindsay JR, Newell-Price J, Nieman LK, Petersenn S, Sonino N, Stalla GK, Swearingen B, Vance ML, Wass JAH \& Boscaro M. Treatment of adrenocorticotropindependent Cushing's syndrome: a consensus statement. Journal of Clinical Endocrinology and Metabolism 200893 2454-2462. (doi:10.1210/jc.2007-2734)

22 Ramachandran P, Penhoat A, Naville D, Begeot M, Osama Abdel-Wareth L \& Reza Sedaghatian M. Familial glucocorticoid deficiency type 2 in two neonates. Journal of Perinatology 200323 62-66. (doi:10.1038/sj.jp.7210813)

23 Fluck CE, Martens JW, Conte FA \& Miller WL. Clinical, genetic, and functional characterization of adrenocorticotropin receptor mutations using a novel receptor assay. Journal of Clinical Endocrinology and Metabolism 200287 4318-4323. (doi:10. 1210/jc.2002-020501)

24 Imamine H, Mizuno H, Sugiyama Y, Ohro Y, Sugiura T \& Togari H. Possible relationship between elevated plasma ACTH and tall stature in familial glucocorticoid deficiency. Tohoku Journal of Experimental Medicine 2005205 123-131. (doi:10.1620/tjem. 205.123)

25 Collares CV, Antunes-Rodrigues J, Moreira AC, Franca SN, Pereira LA, Soares MM, Elias Junior J, Clark AJ, de Castro M \& Elias LL. Heterogeneity in the molecular basis of ACTH resistance syndrome. European Journal of Endocrinology 2008159 61-68. (doi:10.1530/EJE-08-0079)

26 McEachern R, Drouin J, Metherell L, Huot Cl, Van Vliet G \& Deal C. Severe cortisol deficiency associated with reversible growth hormone deficiency in two infants: what is the link? Journal of Clinical Endocrinology and Metabolism 201196 2670-2674. (doi:10.1210/jc.2011-0129)

27 Akin L, Kurtoglu S, Kendirici M \& Akin MA. Familial glucocorticoid deficiency type 2: a case report. Journal of Clinical Research in Pediatric Endocrinology 20102 122-125. (doi:10. 4274/jcrpe.v2i3.122)

Received 1 July 2011

Revised version received 7 September 2011

Accepted 22 September 2011 